\title{
Expression of Klebsiella pneumoniae Nitrogen Fixation Genes in Nitrate Reductase Mutants of Escherichia coli
}

\author{
By CHRISTINA KENNEDY AND J. R. POSTGATE \\ A.R.C. Unit of Nitrogen Fixation, University of Sussex, Brighton BNI $9 Q J$
}

(Received I3 September 1976)

\begin{abstract}
SUMMAR Y
Nitrate reductase (nar) $A, B$ and $E$ mutants of Escherichia coli with plasmids carrying Klebsiella pneumoniae nitrogen fixation (nif) genes reduced acetylene independently of added molybdate, but nar $D$ mutants showed pleiotropic dependence on the concentration of added molybdate for expression of both nar and nif. No complementation of nar mutations by nif occurred; nitrite but not nitrate repressed nif in nar hosts. Derepression of nif occurred in molybdenum-deficient nar $D$ (nif) strains since nitrogenase peptides were present. nif $B$ mutants, thought to have a lesion in the pathway of molybdenum to nitrogenase, as well as nif deletion mutants, had normal nitrate reductase activity.
\end{abstract}

\section{INTRODUCTION}

Nitrogenase and nitrate reductase are both multimeric molybdoproteins and correlations in structure, function and incidence have been suggested. In pot studies, a correlation between the nitrate reductase content of Rhizobium japonicum and symbiotic efficiency was noted (see Cheniae \& Evans, 1960; Evans \& Russell, 197I), which gained support at the genetic level from the observation by Kondorosi et al. (1973) that nitrate reductase mutants of $R$. meliloti had lost effectiveness in plant nodulation but regained it on reversion (Sik et al., 1976). At the molecular level, a molybdenum-containing fragment generated by acid treatment of nitrogenase, or other molybdoenzymes, complements nitrate reductase activity in the nit-I mutant of Neurospora crassa (see Pan et al., 1976). Acid-treated nitrogenase restored acetylene-reducing activity to extracts of the nif $B$ class of nitrogen-fixation mutants of Klebsiella pneumoniae (St John et al., 1975). Klebsiella Nif- mutants which pleiotropically showed chlorate resistance were mentioned by Streicher, Gurney \& Valentine (I97I), and Tubb (I974) described a regulatory $\mathrm{Nif}^{-}$mutant which was pleiotropically negative in assimilatory nitrate reduction.

Among the characterized nitrate reductase mutants in Escherichia coli (Venables, 1972) is a class, $\operatorname{nar} D$, in which nitrate reductase activity is restored by high levels of added molybdate (Glaser \& De Moss, I97I; Sperl \& De Moss, 1975). This organism contains Pichinoty's (1973) class A nitrate reductase for which chlorate is a substrate and is converted to the toxic chlorite; chlorate resistance thus correlates with absence of dissimilatory nitrate reductase activity and the $c h l$ and nar genotypes are identical. We shall use the nar nomenclature in this paper, which reports studies on the expression of $K$. pneumoniae nif genes introduced into various nar mutants of $E$. coli, and on the nitrate reductase activity of certain nif mutants of $K$. pneumoniae. 


\section{METHODS}

Organisms and culture. Table I lists the bacteria used, their genotypes and sources. They were maintained on nutrient agar slopes, with appropriate selection for drug-resistance markers in strains carrying nif plasmids.

For most tests we used a low-nitrogen medium (NFDM; Cannon et al., 1974) containing Casamino acids (100 $\mu \mathrm{g} \mathrm{ml}^{-1}$ ) but with no added molybdate. Concentrated phosphate buffer was extracted with 8-hydroxyquinoline and $\mathrm{CHCl}_{3}$ before being autoclaved and added to the medium, which was prepared and used in acid-washed glassware. Sterile sodium molybdate, sodium nitrate or sodium nitrite was added as necessary and the following supplements required by the nar strains were included if needed $\left(\mu \mathrm{g} \mathrm{ml}^{-1}\right)$ : thiamin, I ; L-leucine, L-threonine and L-histidine, 20; biotin, I. Complete media were Oxoid no. 2 broth solidified with $\mathrm{I} \cdot 5 \%(\mathrm{w} / \mathrm{v})$ agar with, if necessary, the following additions $\left(\mu \mathrm{g} \mathrm{ml}^{-1}\right)$ : streptomycin, 200; carbenicillin, I00; kanamycin, 20. For chlorate resistance tests, $\mathrm{KClO}_{3}$ was added to $50 \mu \mathrm{mol} \mathrm{ml}^{-1}$.

Plasmid transfer. Escherichia coli $\mathrm{JC} 5466$ carrying the F prime plasmid FN68 was mated with $E$. coli nar recipients in broth at $37^{\circ} \mathrm{C}$ for $\mathrm{I}$ to $\mathrm{I} \cdot 5 \mathrm{~h}$ and exconjugants were selected for $\mathrm{Sm}^{\mathrm{r}}, \mathrm{Cb}^{\mathrm{r}}$. The same donor carrying the $\mathrm{P}$ prime plasmid $\mathrm{RP}_{4} \mathrm{I}$ was mated with nar recipients on nutrient agar for $6 \mathrm{~h}$ at $37^{\circ} \mathrm{C}$ and exconjugants were selected for $\mathrm{Sm}^{\mathrm{r}}, \mathrm{Cb}^{\mathrm{r}}, \mathrm{Km}^{\mathrm{r}}$.

Transduction. Bacteriophage PIclr $100 \mathrm{Km}$ was used as described by Goldberg, Bender \& Streicher (1974) to transduce various his-linked nif mutations into K. pneumoniae hisD2 nif ${ }^{+}$ strain Kp5022. Phage lysates were prepared from Prclrioo Km lysogens of the his ${ }^{+}$nif mutants. The recipient strain Kp5022 was infected with phage and subsequently plated on minimal glucose medium to select for $\mathrm{His}^{+}$transductants. Colonies were patched on NFDM agar plates and incubated anaerobically to screen for cotransduction of nif.

Enzyme activity. Nitrate reductase activity was assessed qualitatively as nitrite formed either after growth for 16 to $20 \mathrm{~h}$ at $37^{\circ} \mathrm{C}$ in stationary tubes of Oxoid dextrose/peptone broth containing $0.1 \%(\mathrm{w} / \mathrm{v}) \mathrm{KNO}_{3}$ or after anaerobic growth under argon in the Mo-free low-nitrogen glucose medium containing $\mathrm{NaNO}_{3}$ (Io $\mathrm{mg} \mathrm{ml}^{-1}$ ). A more precise assessment was obtained by anaerobic culture for $\mathrm{I} 6$ to $20 \mathrm{~h}$ in NFDM plus Casamino acids; $\mathrm{NaNO}_{3}$ was added to $0.25 \mathrm{mg} \mathrm{ml}^{-1}$ and, after 30 to $60 \mathrm{~min}$ at $37^{\circ} \mathrm{C}$, nitrite formation in $\mathrm{I} \mathrm{ml}$ of culture was assessed colorimetrically and graded visually. Diazotization of sulphanilic acid by a portion of culture followed by coupling with 'Cleve's acid' (Trollope \& Evans, 1975) or $\beta$-naphthylamine was used to obtain a pink coloration.

Nitrogenase activity was assessed by the acetylene-reduction method. Cultures in nutrient broth were diluted $\mathrm{I}: 50$ in $3.5 \mathrm{ml}$ portions of NFDM plus Casamino acids medium in $5 \mathrm{ml}$ sterile bijou bottles capped with Suba-Seal rubber closures. After shaking at $30^{\circ} \mathrm{C}$ for I 6 to $36 \mathrm{~h}$ to allow derepression of nitrogenase synthesis, I $\mathrm{ml} \mathrm{C}_{2} \mathrm{H}_{2}$ was injected and 30 to 60 min later the amount of $\mathrm{C}_{2} \mathrm{H}_{4}$ formed was measured on a Pye gas chromatograph with a $20 \mathrm{~cm}$ column of Porapak $\mathrm{N}$ and a flame ionization detector working in a stream of $\mathrm{N}_{2}$.

Electrophoresis. Derepressed cells grown at $30^{\circ} \mathrm{C}$ under $\mathrm{N}_{2}$ in NFDM plus Casamino acids for 36 to $48 \mathrm{~h}$, and repressed control cells grown similarly but with $\mathrm{NH}_{4} \mathrm{Cl}$ (I mg ml $\left.\mathrm{m}^{-1}\right)$ were centrifuged, and the pellet was resuspended in $0.2 \mathrm{ml}$ buffer containing sodium dodecyl sulphate $\left(20 \mathrm{mg} \mathrm{ml}^{-1}\right.$ ) and heated in a boiling water bath for $2 \mathrm{~min}$. Extract ( $75 \mu 1$ containing about $250 \mu \mathrm{g}$ bacterial protein) was loaded into each sample well of an SDS-polyacrylamide slab gel prepared according to the Ortec buffer recipes (Kennedy et al., 1976) in order to ensure that the two subunit peptides of nitrogenase Mo-Fe protein resolved into two bands 
Table I. Bacterial strains and plasmids

Strain

E. coli $\mathrm{KI} 2$

R594

C198

C21 8

$\mathrm{C} 2 \mathrm{O} 2$

w602

CIII

JC5466

$K$. pneumoniae M5a I

Kp5022

$\Delta 52$

$\Delta \mathrm{IO} 7$

UNI42

UNI 50

UN3I6

UN3I 8

UN328

UN364

UN587

Plasmids

FN68

RP4I
Genotype*

thr leu thi bio strA gal
R594 nar
R594 narB
R594 narE
thr leu thi bio strA
W602 narD
trp rec A56 his spc

hisD2 nif ${ }^{+}$str

$\Delta$ (gnd-his-nif)

$\Delta$ (gnd-his-nif)

nif $H$ his $D$

nifB hisD

nifD hisD

nifE his $D$

nif $B$ his $D$

nifH his D

nifF his

$\mathrm{F}^{\prime}$ his nif $\mathrm{Cb}^{\mathrm{r}}$

$\mathrm{P}^{\prime}$ his nif $\mathrm{Cb}^{\mathrm{r}} \mathrm{Km}^{\mathrm{r}} \mathrm{Tc}^{\mathrm{r}}$
Source or reference
Venables (1972)

Venables (1972)

Venables (1972)

Venables (I972)

Venables (I972)

Venables (1972)

N. Willetts

Streicher et al. (1974)

S. Streicher

R. A. Dixon

St John et al. (1975)

St John et al. (1975)

St John et al. (1975)

St John et al. (1975)

St John et al. (1975)

St John et al. (1975)

St John et al. (1975)

Cannon, Dixon \& Postgate (I976a)

Dixon, Cannon \& Kondorosi (1976)

* Symbols for chromosome markers after Bachmann, Low \& Taylor (1976). Symbols for plasmiddetermined drug resistance are: $\mathrm{Cb}$, carbenicillin; $\mathrm{Km}$, kanamycin; $\mathrm{Tc}$, tetracycline.

during electrophoresis. Gels were stained with Coomassie blue. In these conditions, derepressed cells yield about 28 bands on the gels of which three prominent ones correspond in position to the two subunits of nitrogenase Mo-Fe protein and the single subunit of nitrogenase Fe protein. These three are absent from gels from $\mathrm{NH}_{4}{ }^{+}$-repressed cells. Nitrogenase represents 10 to $\mathrm{I} 5 \%$ of total cell protein in fully-derepressed cells. Nitrogenase levels lowered more than 5- to I0-fold (I0 to $20 \%$ of fully-derepressed levels) would not be detected by this method.

\section{RESULTS}

The nar ${ }^{+}$strains E. coli $\mathrm{R} 594$ and $\mathrm{w} 602$ and the four nitrate reductase mutants (narA, nar $B$, nar $D$, narE) into which the plasmids FN68 or RP4I were introduced showed normal nitrogenase activities in media with molybdate at $10^{-4} \mathrm{M}$. All parent strains and nar mutants without plasmid were inactive. The nar $D$ mutants, but none of the other strains carrying RP4I, showed a requirement for added molybdenum comparable to that reported by Glaser \& De Moss (I97I) for nitrate reduction (Table 2). The possession of RP4I did not restore the $\mathrm{Nar}^{+}$phenotype to any of the mutants, whether in growth tests, in nitrite formation or in restoration of chlorate sensitivity. Comparable checks for chlorate sensitivity or nitrite formation were negative in nar mutant strains carrying FN68.

The dependence of nitrogenase activity on molybdate concentration in a nar $D$ background was investigated further. When $E$. coli $\left.\mathrm{CIII}_{(\mathrm{RP}} \mathrm{I}\right)$ was grown without added molybdate, addition of molybdate followed by acetylene $2 \mathrm{~h}$ later restored the $\mathrm{Nif}^{+}$phenotype (Table 3). When chloramphenicol (100 $\mu \mathrm{g} \mathrm{ml}^{-1}$ ) was added shortly before the molybdate, it prevented subsequent expression of acetylene-reducing activity. SDS-polyacrylamide gel electrophoresis of extracts from CII I(RP4I) grown without added molybdate showed the presence of nitrogenase proteins in normal derepressed amounts. Inactive nitrogenase was 


\section{Table 2. Nitrogenase and nitrate reductase activities of nar ${ }^{+}$and nar strains of E. coli}

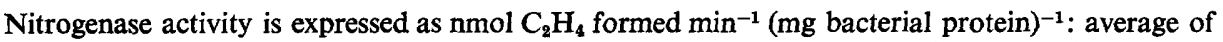
two to four tests. Nitrite formation was determined colorimetrically as described in Methods: ++ , dark pink, strongly positive; + , light pink; - , colourless, negative. Growth on nitrate was indicated by colony formation or cell turbidity in liquid medium: +, growth; -, no growth. S, sensitive; $\mathbf{R}$, resistant; NT, not tested.

\begin{tabular}{|c|c|c|c|c|c|}
\hline \multirow[b]{2}{*}{ Strain } & \multicolumn{2}{|c|}{ Nitrogenase activity } & \multicolumn{3}{|c|}{ Nitrate reductase activity detected by : } \\
\hline & $\begin{array}{c}\mathrm{No} \mathrm{Na}_{2} \mathrm{MoO}_{4} \\
\text { added }\end{array}$ & $\begin{array}{c}\mathrm{I} 00 \mu \mathrm{M}-\mathrm{Na}_{2} \mathrm{MoO}_{4} \\
\text { added }\end{array}$ & $\begin{array}{c}\text { Nitrite } \\
\text { formation }\end{array}$ & $\begin{array}{l}\text { Growth on } \\
\text { nitrate }\end{array}$ & $\begin{array}{l}\text { Chlorate } \\
\text { resistance }\end{array}$ \\
\hline R594 nar $^{+}$ & NT & 0 & ++ & + & $\mathbf{s}$ \\
\hline R594(RP4I) & 75 & 85 & ++ & + & $\mathbf{s}$ \\
\hline w602 nar $^{+}$ & NT & 0 & + & + & $\mathrm{NT}$ \\
\hline w602(RP4I) & 35 & 42 & + & + & NT \\
\hline CI98 nar $A$ & NT & 0 & - & - & $\mathbf{R}$ \\
\hline CI98(RP4I) & 65 & 53 & - & - & $\mathbf{R}$ \\
\hline $\mathrm{C} 2 \mathrm{I} 8 \operatorname{nar} B$ & NT & o & - & - & $\mathbf{R}$ \\
\hline C2 I 8(RP4I) & 25 & 27 & - & - & $\mathbf{R}$ \\
\hline $\mathrm{C} 202$ narE & NT & 0 & - & - & $\mathbf{R}$ \\
\hline${\mathrm{C} 202\left(\mathrm{RP}_{4} \mathrm{I}\right)}$ & 15 & 25 & - & - & $\mathbf{R}$ \\
\hline \multirow[t]{2}{*}{ CIII narD } & 0 & 0 & $\left(-\mathrm{MoO}_{4}{ }^{2-}\right)-$ & - & $\mathrm{NT}$ \\
\hline & & & $\left(+\mathrm{MoO}_{4}{ }^{2-}\right)+$ & + & NT \\
\hline \multirow[t]{2}{*}{ CI I I(RP4I) } & $<0.3$ & 30 & $\left(-\mathrm{MoO}_{4}{ }^{2-}\right)-$ & - & NT \\
\hline & & & $\left(+\mathrm{MoO}_{4}{ }^{2-}\right)+$ & + & NT \\
\hline
\end{tabular}

Table 3. Molybdate dependence of nitrogenase activity in E. coli

$$
\text { CIII(RP4I) nar D }
$$

Bacteria were grown without added molybdate as described in Methods. After $20 \mathrm{~h}$ molybdate was added and the cultures were shaken for $2 \mathrm{~h}$. Acetylene was then added to each bottle and ethylene formation was measured after 30 to $60 \mathrm{~min}$. Nitrogenase activity is expressed as nmol $\mathrm{C}_{2} \mathrm{H}_{4}$ formed $\mathrm{min}^{-1}(\mathrm{mg} \text { protein })^{-1}$.

$\begin{array}{cc}\mathrm{Na}_{2} \mathrm{MoO}_{4} \text { added }(\mathrm{M}) & \text { Nitrogenase activity } \\ 0 & <0.5 \\ 10^{-8} & <0.5 \\ 10^{-7} & <0.5 \\ 5 \times 10^{-7} & 1.4 \\ 10^{-6} & 2 \\ 5 \times 10^{-6} & 19 \\ 10^{-5} & 18 \\ 10^{-4} & 20 \\ 10^{-3} & 16\end{array}$

thus present in the Mo-deficient narD (nif) mutant and protein synthesis was necessary for its activation after addition of molybdate.

Repression of nitrogenase by nitrate. Nitrate, like ammonia, prevents expression of nitrogenase activity but several mechanisms other than direct co-repression at the genetical level by nitrate might operate. For example, Sorger (1969) showed that a chlr mutant of the aerobe Azotobacter vinelandii escaped nitrate repression of nitrogenase activity. Nitrogenase activities of various $E$. coli strains carrying nif genes on $\mathrm{RP}_{4} \mathrm{I}$ were tested after growth in NFDM plus Casamino acids with nitrite or nitrate. Nitrite repressed nitrogenase activity in all strains tested, but the $\operatorname{nar} A\left(\mathrm{RP}_{4} \mathrm{I}\right)$ and $\operatorname{nar} B\left(\mathrm{RP}_{4} \mathrm{I}\right)$ strains grown in nitrate showed nearly normal levels of acetylene reduction (Table 4) (narD and narE were not tested). 
Table 4. Nitrate and nitrite repression of nitrogenase in nar mutants of $E$. coli

Cultures of nar mutants and of the parent type carrying nif plasmids were grown anaerobically in NFDM plus Casamino acids at $37^{\circ} \mathrm{C}$ with or without the supplements listed. Nitrogenase activity

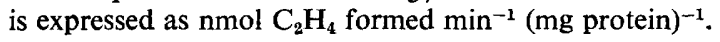

$\begin{array}{clc}\text { Strain } & \begin{array}{c}\text { Supplement } \\ (20 \mathrm{mM})\end{array} & \begin{array}{c}\text { Nitrogenase } \\ \text { activity }\end{array} \\ \text { R594(RP4I) } \text { nar }^{+} & \text {None } & 75 \\ & \mathrm{NaNO}_{3} & \mathrm{I} \cdot 7 \\ & \mathrm{NaNO}_{2} & <0 \cdot 2 \\ \text { C198(RP4I) narA } & \mathrm{None} & 5 \mathrm{I} \\ & \mathrm{NaNO}_{3} & 39 \\ \mathrm{NaNO}_{2} & <0 \cdot 2 \\ \text { C218(RP4I) narB } & \mathrm{None} & 68 \\ & \mathrm{NaNO}_{3} & 34 \\ & \mathrm{NaNO}_{2} & 0.5\end{array}$

SDS-polyacrylamide gel electrophoresis of extracts prepared from these strains showed no nitrogenase proteins in nitrite-grown cells nor in nar $^{+}$nitrate-grown cells. It follows that nitrate is not itself a co-repressor but must be metabolized to nitrite in order to repress synthesis of nitrogenase.

Nitrogenase and the nifB locus. The nif cluster includes the gene nifB which is probably concerned with the incorporation of Mo into nitrogenase. In view of the pleiotropy between nif and nar $D$, the question arises whether nifB shows pleiotropy with nitrate reduction. All the UN strains in Table I (nifF, nifH, nifD, nifE, as well as nif $B$ ) were chlorate-resistant and lacked nitrate reductase activity; hence they were unsuitable for a direct test of this question. His $^{+}$revertants of the UN strains were therefore selected and their mutant nif genes were

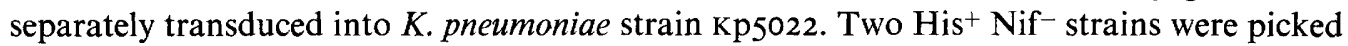
from each transduction; all showed full nitrate reductase activity, including the nif $B$ transductants. Strains $\Delta_{52}$ and $\Delta_{107}$ of $K$. pneumoniae which have chromosomal deletions extending through nifB (Dixon et al., 1977) grew normally with nitrate as nitrogen source and formed nitrite.

\section{DISCUSSION}

The expression of $K$. pneumoniae nif genes in nar mutants of $E$. coli shows clear pleiotropy between nif expression and mutation in the nar $D$ gene, which is involved in assimilation of the molybdenum necessary for nitrate reductase activity. An earlier report to the contrary (Cannon et al., 1976 b) was mistaken and arose from a confusion of medium recipes in our laboratory. The probability is that the nar $D$ locus specifies a molybdenum insertase rather than an uptake protein, the insertion taking place at high molybdate concentration (Sperl \& De Moss, 1975). Evidently nar and nif share some Mo-processing functions. The nif $B$ locus is clearly quite distinct from nar $D$. It shows no pleiotropy with nar expression; the nar $D$ locus maps at $17 \mathrm{~min}$ in $E$. coli compared with $39 \mathrm{~min}$ for his $D$; nif $B$ is part of the nif cluster, close to his $D$ in $K$. pneumoniae, and is presumably absent from $E$. coli. It follows that nar $D$ mutants of $K$. pneumoniae might be pleiotropically $\mathrm{Nif}^{-}$and the converse event, Nifmutants which show a $\mathrm{Nar}^{-}$phenotype, could be of the nar $D$ class as well as of the regulatory class already described. They should be readily detectable by their chlorate resistance; some of those mentioned by Streicher et al. (1971) may have been of this class, but the frequencies of cotransduction with his $D$ suggest that some may have been fortuitous double mutants: the rate of forward mutation to Chl $\mathrm{r}$ in $K$. pneumoniae can be very high (unpublished observations). 
The nar $D$ mutation is always somewhat leaky: faint nitrite colorations occur and, in our hands, marginally low levels of nif expression are detected if a nif plasmid is present. This leakiness can be attributed to contaminating Mo in the media used, since there was obviously sufficient, without added Mo, to satisfy the requirements of the various $\mathrm{Nif}^{+} E$. coli and $K$. pneumoniae strains used in our experiments.

Our finding that Mo-deficient $E$. coli narD(RP4I) contains normal amounts of the three nitrogenase peptides is in contrast to the results of Brill, Steiner \& Shah (1974), who found no antigenically cross-reacting material to either the Mo-Fe or Fe nitrogenase proteins in $K$. pneumoniae derepressed in the absence of Mo. The absence of nitrogenase proteins could be explained by their use of non-growing $\mathrm{N}_{2}$-dependent cells in which net protein synthesis was severely reduced and derepression thereby possibly impaired. In our experiment, nitrogenase activity was not necessary for growth since cells were provided with a nonrepressive source of nitrogen and we could detect formation of inactive nitrogenase. An unlikely possibility is that nif derepression is Mo-dependent in $K$. pneumoniae but not in E. coli carrying nif genes. In any case our experiments provide no evidence for Mo being an inducer of nif gene expression.

We are indebted to Miss Thea Scott and Mrs Linda Witts for assistance with these experiments. We thank Dr W. A. Venables for the nar strains of $E$. coli and Professor W. J. Brill for the UN series of nif mutants of K. pneumoniae.

\section{REFERENCES}

Bachmann, B. J., Low, K. B. \& TAYLOR, A. L. (1976). Recalibrated linkage map of Escherichia coli K-I2. Journal of Bacteriology 40, I I6-I67.

Brill, W. J., Steiner, A. L. \& SHAH, V. K. (1974). Effect of molybdenum starvation and tungsten on the synthesis of nitrogenase components in Klebsiella pneumoniae. Journal of Bacteriology 118, 986-989.

Cannon, F. C., Dixon, R. A., Postgate, J. R. \& Primrose, S. B. (1974). Chromosomal integration of nitrogen fixation genes in Escherichia coli. Journal of General Microbiology 80, 227-240.

Cannon, F. C., Dixon, R. A. \& Postgate, J. R. (1976a). Derivation and properties of F-prime factors in Escherichia coli carrying nitrogen fixation genes from Klebsiella pneumoniae. Journal of General Microbiology 93, I I I-I 25.

Cannon, F. C., Kennedy, C., Postgate, J. R., Tubb, R. S. \& Dixon, R. A. (1976b). Construction of an F-prime factor carrying the Klebsiella pneumoniae nif genes: a genetic tool for anaylsis of the nif system. In Proceedings of the First International Symposium on Nitrogen Fixation, vol. 2, pp. 320-326. Edited by W. E. Newton and C. J. Nyman. Pullman, Washington: Washington State University Press.

Cheniae, G. M. \& Evans, H. J. (I960). Physiological studies on nodule nitrate reductase. Plant Physiology 35, 454-462.

Dixon, R. A., Cannon, F. C. \& Kondorosi, A. (1976). Construction of a P plasmid carrying nitrogen fixation genes from Klebsiella pneumoniae. Nature, London 260, 268-27I.

Dixon, R. A., Kennedy, C., Kondorosi, A., Krishnapillai, V. \& Postgate, J. R. (1977). Genetic analysis of nitrogen fixation in $K$. pneumoniae. In Proceedings of the Second International Symposium on Nitrogen Fixation, Salamanca, Spain, 1976 (in the Press).

Evans, H. J. \& Russell, S. A. (197I). Physiological chemistry of symbiotic nitrogen fixation by legumes. In The Chemistry and Biochemistry of Nitrogen Fixation, pp. 191-244. Edited by J. R. Postgate. London and New York: Plenum Press.

Glaser, J. H. \& De Moss, J. A. (I97I). Phenotypic restoration by molybdate of nitrate reductase activity in chlD mutants of Escherichia coli. Journal of Bacteriology 108, 854-860.

Goldberg, R. B., Bender, R. A. \& Streicher, S. L. (I974). Direct selection for Pi-sensitive mutants of enteric bacteria. Journal of Bacteriology I18, 810-814.

KENNEDY, C., EADY, R. R., Kondorosi, E. \& REKosh, D. (I976). The molybdenum-iron protein of $K$. pneumoniae nitrogenase. Evidence for non-identical subunits from peptide mapping. Biochemical Journal 155, 383-389.

Kondorosi, A., Barabas, I., Svab, Z., Orosz, L., Sik, T. \& Hotchkiss, R. D. (1973). Evidence for common determinants of nitrogenase and nitrate reductase in Rhizobium meliloti. Nature New Biology 246 , I53-I54. 
Pan, S.-S., Erickson, R. H., LeE, K-Y. \& NASON, A. (1976). Molybdenum-containing component shared by the molybdenum enzymes as indicated by the in vitro assembly of assimilatory nitrate reductase using the Neurospora mutant nit-I. In Proceedings of the First International Symposium on Nitrogen Fixation, vol. I, pp. 293-3II. Edited by W. E. Newton and C. J. Nyman. Pullman, Washington: Washington, State University Press.

Pichinoty, F. (1973). La réduction bactérienne des composés oxygénés minéraux de l'azote. Bulletin de l'Institut Pasteur 71, 317-395.

St John, R. T., Johnston, H. M., Seidman, C., Garfinkel, D., Gordon, J. K., Shah, V. \& Brill, W. J. (I975). Biochemistry and genetics of Klebsiella pneumoniae mutant strains unable to fix $\mathrm{N}_{2}$. Journal of Bacteriology 125, 759-765.

Sik, T., Kondorosi, A., BaRABas, I. \& Svab, Z. (1976). Nitrate reductase and effectiveness in Rhizobium. In Proceedings of the First International Symposium on Nitrogen Fixation, vol. 2, pp. 374-382. Edited by W. E. Newton and C. J. Nyman. Pullman, Washington: Washington State University Press.

SORGER, G. J. (1969). Regulation of nitrogen fixation in Azotobacter vinelandii oP: role of nitrate reductase. Journal of Bacteriology 98, 56-61.

SPERL, G. T. \& DE Moss, J. A. (1975). chlD function in molybdate activation of nitrate reductase. Journal of Bacteriology 122, 1230-I 238.

Streicher, S. L., Gurney, E. \& Valentine, R. C. (I97I). Transduction of the nitrogen-fixation genes in Klebsiella pneumoniae. Proceedings of the National Academy of Sciences of the United States of America 68, 1174 .

Streicher, S. L., Shanmugan, K. T., Ausubel, F., Morandi, C. \& Goldberg, R. B. (I974). Regulation of nitrogen fixation in $K$. pneumoniae: evidence for a role of glutamine synthetase as a regulator of nitrogenase synthesis. Journal of Bacteriology 129, 81 5-82 I.

Trollope, D. R. \& Evans, B. (1975). Testing for nitrate reduction by bacteria: the use of Cleve's acid (8-aminonaphthalene-2-sulphonic acid) to determine nitrite formation. Laboratory Practice 24, 253.

TUBB, R. S. (I 974). Glutamine synthetase and ammonium regulation of nitrogenase synthesis in Klebsiella. Nature, London 25r, $48 \mathrm{I}-485$.

VenABles, W. A. (1972). Genetic studies with nitrate reductase-less mutants of Escherichia coli. Molecular and General Genetics 114, 223-23I. 